\title{
I and 2 Thessalonians Through the Centuries, by Anthony C. Thiselton
}

\author{
Blackwell Bible Commentaries | Chichester and Malden: Wiley- \\ Blackwell, 20I I xvi + 3I7 pages | ISBN: 978-I-405I-9682- \\ 6 (hardcover) $£ 83.50$ | ISBN: 978-I-4443-90I4-8 (ebook) \\ E75.99
}

This timely and interesting series purports to focus on the reception history of books of the Bible, rather than

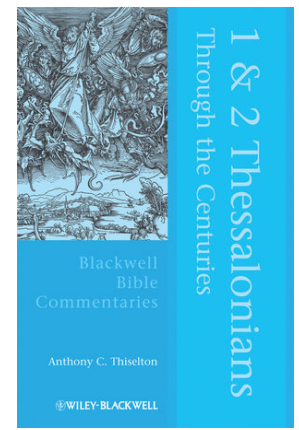
on the question of what biblical books originally were intended by their authors/editors/compilers to have meant. Thus, a significant part of what this commentary deals with is how different biblical commentators and perhaps others have dealt with I and 2 Thessalonians, since these were written in the middle-to-late first century of the Common Era.

Yet the traditional concerns of historical criticism are not completely overlooked in this commentary. After an exposition of reception history on pages I-7, Thiselton does deal with what he terms "The Situation and Substance of I Thessalonians" on pages 7-IO, followed by material about the historical situation of Thessalonians in the late first century BCE. and in Paul's century. We read of the loyalty of the city of Thessalonica to Rome, so that "[a] ny 'troublemaker' who tried to rock the boat would not be tolerated" (I I). Thiselton concludes that " $\mathrm{t}]$ he Acts account of the charges and the riot is all the more plausible in this light" (ibid.), so that his reading of the history of Thessalonica confirms the historical accuracy of Acts I7, which, as New Testament scholars are very aware, has a profound effect on the interpretation of I Thessalonians and especially 2 Thessalonians.

Historical criticism continues unabated with a new section, "Traditional and Nineteenth-Century Arguments about the Authenticity of 2 Thessalonians and Their Criticism" (ibid.). We are told that no scholar "doubted" the sequence of $\mathrm{I}$ and 2 Thessalonians before Hugo Grotius, and no one doubted the "traditional" authorship (meaning authorship by Paul) until Johann Ernst Christian Schmidt in I 80 I (ibid.). Hence, the positing of authorship for 2 Thessalonians other than by the Apostle Paul is referred to as a "doubt," which hardly seems to be the most objective way of dealing with the issue which has been (and remains) at the center of the interpretation of 2 Thessalonians since the early nineteenth century, namely for the past 200 years. The next page features a subsection entitled, with equal one-sidedness, 
"Attacks on the authenticity of 2 Thessalonians in the nineteenth century" (I 2-I 4). On the "[s]ituation and [s]ubstance of 2 Thessalonians," Thiselton tells his readers, "We simply do not know the exact date of the Second Epistle, but it contains sufficient echoes of the First to assume that Paul wrote both within a very short period..." (I 5 ). Why exactly should one "assume" that Paul wrote 2 Thessalonians, given that something like a bare majority of current critical commentators, internationally, appears not to agree with this assumption?

As this commentary proceeds after the Introduction to both Thessalonian letters, it focuses on the usual assortment of pericopes of the letters in their canonical order. In these sections, there is commentary based on comments by writers of the patristic era, the middle ages, the eras of the sixteenth-century Reformation and Post-Reformation, the eighteenth century, and the nineteenth century. In the "Introduction and Overview" of each pericope of text, often twentieth-century and contemporary scholars are quoted and cited. Many New Testament scholars are familiar with Hugo Grotius's reversal of the historical order of I and 2 Thessalonians in his Annotationes in Novum Testamentum in I64I, yet it is a new experience for most of us to see comments by Tertullian, John Chrysostom, Rabanus Maurus, Lanfranc of Canterbury, Martin Luther, William Estius, James Arminius, Lancelot Andrewes, George Herbert, and Benjamin Jowett in the same volume with the critical issues of introduction featuring late-nineteenth-century and twentieth-century scholarship. It is a reminder to contemporary New Testament scholars that all sorts of people-mystics, poets, scholars, and preachers through many centuries- have read and thought deeply as they interpreted the New Testament. The writing of this commentary by Thiselton clearly was a massive task, and much of the task was his deciding which bits and pieces from the past to include, and which to pass over in silence. So this commentary, like all others which used quite different methods, was very much a matter of interpretation by its learned author.

Various passages are treated in different ways, based on how the Christian tradition has interpreted the passages in question. I Thessalonians 4:4 contains the famous sentence in which Paul's readers are advised to ktasthai their skeuos in holiness and honor. Ktasthai usually means "to create," but it can also mean "to acquire" or "to take control of." Skeuos literally means "vessel" but can also mean, more metaphorically, either "wife" or "body" or, as Thiselton does not point out, "penis" (96). Depending on how one translates skeuos, either "acquire" or "take control of" is possible for the translation of 
ktasthai. Subsequent to Paul, commentators have come up with a variety of interpretations with several different rationales, as Thiselton does point out at great length. I Thessalonians 4:I3-I 8 occasions a compact discussion by Thiselton of "the Rapture" in connection with Dispensationalism (I43-5).

There is an extended discussion of the apocalyptic or apocalypse-like features of 2 Thessalonians 2:I-I 2 (2 I I-44). Part of this discussion is to reiterate the arguments of Alexandra Brown, Ernst Käsemann, Klaus Koch, and J. Christiaan Beker in favor of the centrality of apocalyptic to Paul's thought (I6-I7; cf. I9I-2 and 2I2), which, as far as the present reviewer knows, is not controversial at the present time.

This brings us back to the central issue of interpretation of these two New Testament letters: the authorship of 2 Thessalonians. Thiselton has surely shown that there is a wide variety of themes in which scholarship before I90 I was deeply interested, and many of these themes revolve around the interpretation of the apocalyptic material in 2 Thessalonians, especially chapter 2. Not to be forgotten is the material in 2 Thess I:5-I2, where one of the reasons for thanksgiving is the judgment of God on those who do not believe in Christ (2 Thess I:6-8), also an apocalyptic topos.

In dealing with the authorship issue, while it is probably true that some commentators thought the apocalyptic material in 2 Thessalonians to be "too 'Jewish' to have been written by Paul" (I9I), it remains quite true that one of the objections against Pauline authorship of 2 Thessalonians is that Paul in I Thess 5: I-3 says that the Day of the Lord will come suddenly, without any intervening signs, in contradistinction to 2 Thess 2:3-I 2 where several signs must happen before the Day of the Lord comes. It seems to me that this is an example of a topos of apocalyptic literature being used negatively in one letter and positively in the other. Neither one is more or less Jewish than the other: they rather represent different ways that a familiar topos in apocalypse-like literature can be used.

This reviewer writes as a partisan in the debate over the authorship of 2 Thessalonians. When I was writing my dissertation in I983-84 and the book that came from it, Early Christian Rhetoric and 2 Thessalonians (JSNTSup 30; Sheffield: JSOT Press, I989), I determined that the evidence pointed me, along with quite a few other contemporary scholars, away from Paul's authorship of 2 Thessalonians, I never believed that I was attacking anything or anybody. I thought I was coming to a better understanding of the actual authorship of a letter of the Pauline corpus. I thought I was coming to a more mature understanding of how Paul and Paul's theology were understood 
and further developed after the Apostle's death. To give another example, is it somehow better or more Christian to believe that Paul wrote Ephesians than to believe that he did not? What criteria would one use to answer that question? Surely these would be legitimate questions that anybody working in hermeneutics of the New Testament should take up.

Hence although it is clear that much research has gone into Thiselton's commentary, I am left with a number of questions that hover around the notion of reception history. How does reception history deal with the current era of exegesis, at least going back to Johann Ernst Christian Schmidt, not to mention William Wrede or Glenn S. Holland, or even Charles Homer Giblin, all of whom decided (Giblin changed his mind in favor of nonpauline authorship towards the end of his life) that it is most likely that Paul did not write 2 Thessalonians? Thus, one may legitimately ask whether reception history is meant as a complement to historical criticism or as a corrective to it.

Frank W. Hughes

Minden, Louisiana 